7. Reprod. Fert. (1971) 25, 193-199

\title{
AN IMMUNE RESPONSE TO EGG-YOLK SEMEN DILUENT IN DAIRY COWS
}

\author{
J. F. T. GRIFFIN, W. R. NUNN AND P. J. HARTIGAN \\ School of Veterinary Medicine, Trinity College, Dublin
}

(Received 22nd Fune 1970)

\begin{abstract}
Summary. Antibodies to egg-yolk semen diluent antigens were isolated from the majority of samples from the vagina, uterus and serum of cows which had received repeated artificial inseminations with semen diluted in egg-yolk diluent. The vagina was the site from which antibodies were isolated most frequently. There was evidence that the titres of antibodies in the genital tract resulted in part, at least, from local antibody production by the vaginal and uterine tissues.

Samples with titres to egg-yolk diluent antigens, when tested in vitro, caused mixed agglutination of homologous spermatozoa diluted in eggyolk diluent, while non-specific head-to-head agglutination was seen when the spermatozoa had been diluted in saline. When the cows were inseminated with homologous semen diluted in egg-yolk diluent, the fertility of animals which had uterine titres was significantly lower $(P \geqslant$ $0.05)$ than that of animals which had no titres.

Antibodies to homologous bovine semen were detected in very few uterine samples from animals which had received repeated inseminations.
\end{abstract}

\section{INTRODUCTION}

Since Landsteiner (1899) first discovered the antigenic properties of bovine spermatozoa, antibodies to the semen of mice (McLaren, 1964; Edwards, 1964; Bell, 1969a), rabbits (Edwards, 1960; Behrman \& Nakayama, 1965; Menge, 1968; Bell, 1969b), guinea-pigs (Isojima, Graham \& Graham, 1959; Katsh, 1959) and cattle (Menge, 1967) have been found following iso-immunization of the female with semen or testis. The antigenicity of semen varies from species to species and while guinea-pigs (Isojima et al., 1959) and cattle (Menge, 1967) give a good immunological response, prolonged iso-immunization in the presence of adjuvants is necessary to induce antibodies in mice (McLaren, 1964) and rabbits (Edwards, 1960). Even with cattle, however, chemical adjuvants must be incorporated with the semen or no immunological reaction is found (Kiddy, Stone, Tyler \& Casida, 1959). Fertility is reduced in females showing high serum titres of antibody to homologous spermatozoa following iso-immunization (Katsh, 1959; McLaren, 1964; Behrman \& Nakayama, 1965; Menge, 1967). 
Serum titres of sperm agglutinating antibodies have been demonstrated in cattle following repeated service (Bratanov \& Dikov, 1959; Sokolovskaja \& Reshetnikova, 1968) and in women with a history of unexplained infertility (Franklin \& Dukes, 1964; Tyler, Tyler \& Denny, 1967). However, the work of Menge (1967) has shown that natural service of cattle does not elicit an immune response, even in animals presensitized with homologous semen before service.

With artificial insemination (AI) in cattle, the bovine genital tract is exposed not only to iso-antigenic semen but also to highly antigenic proteins such as egg-yolk and skimmed milk, which are routinely used in solution as diluents for the semen. Bratanov, Dikov \& Popova (1962) have demonstrated serum titres of antibody to egg-yolk semen diluent in heifers inseminated early in the postpartum period with semen diluted in egg-yolk diluent. Subsequently, they observed an allergic response and missed fertilization, when these animals were inseminated with semen diluted in the same diluent.

In this report, serological tests on serum, tissue and mucus samples from the genital tracts of cows receiving repeated inseminations, showed that, although antibody titres to egg-yolk diluent were isolated from the majority of samples, no significant immune response was found to homologous seminal antigens.

\section{MATERIALS AND METHODS}

In a preliminary study, uterine mucus and biopsy samples were collected repeatedly from 104 dairy cows, all of which were impregnated by AI. Samples were taken after insemination and never later than 10 days following service. Animals which had not been inseminated nor served naturally were used as controls. In a second group of sixty-eight cows, all of which were artificially inseminated, samples were taken simultaneously from the vagina, uterus and serum on a single occasion. Ten cows served naturally were used as controls.

Biopsy samples were obtained from the vagina and uterus using an instrument designed by Hartigan, Murphy \& Nunn (unpublished data). Mucus was obtained with this instrument and with cotton wool swabs introduced into the tract by the technique used for microbiological sampling (Murphy, 1967). All samples were transferred to 2-ml amounts of physiological saline and stored at $4^{\circ} \mathrm{G}$. Tissue samples were homogenized with a ground-glass pestle and mortar and centrifuged to remove cellular débris. The mucus was solubilized with glass beads on a vibrator (Fisons) before centrifugation. Blood was collected from the jugular vein and the serum decanted after clotting. All test samples were heated at $56^{\circ} \mathrm{G}$ for $30 \mathrm{~min}$ and stored at $-19^{\circ} \mathrm{G}$.

The AI station responsible for the insemination of the test animals supplied samples of fresh bovine semen which had been stored at $4^{\circ} \mathrm{G}$, and also samples of semen which had been diluted in egg-yolk diluent and stored at $4^{\circ} \mathrm{C}$ or deep frozen in liquid nitrogen. All semen samples were washed five times in Krebs' buffered saline (Wales, Martin \& O'Shea, 1967) before use in the agglutination tests. Seminal plasma was obtained by centrifuging the semen samples at $2500 \mathrm{rev} / \mathrm{min}$ for $10 \mathrm{~min}$. Lactose egg-yolk diluent (Nagassi) was used for the dilution of semen and the tests in vitro. 
A modification of the passive haemagglutination test of Boyden (1951) was used to detect antibodies to seminal plasma and egg-yolk diluent. Human $(\mathrm{ORh}+)$ red blood cells, preserved by treatment with formalin (Weir, 1967), were treated with tannic acid before coating with the test antigen. Haemagglutination inhibition tests were carried out using soluble antigen, in order to confirm the specificity of the reaction. Untreated 'tanned' cells and negative sera were used as controls. Sperm agglutination tests were carried out using the microscopic technique of Kiddy et al. (1959) and the macroscopic agglutinationin-gel reaction of Kilbrick, Balding \& Merrill (1952). In the sperm immobilization test (Ashitaka, Isojima \& Ukita, 1964), human serum was used as a source of complement. Negative sera and saline were used as controls in all tests.

In all immunological tests, titres of less than 16 were found with the control samples, so that only titres greater than this were regarded as positive.

\section{RESULTS}

In the preliminary study, antibodies to egg-yolk diluent were demonstrated frequently in the homogenates of uterine mucus and biopsy samples taken from the 104 dairy cows. The frequency with which positive titres were found rose concomitantly with the number of services the animal had received before collection of the sample (Table 1). Antibody titres to egg-yolk diluent were

\section{TABLE 1}

\begin{tabular}{l} 
THE CORRELATION BETWEEN THE \\
INGIDENGE OF UTERINE ANTIBODY \\
TITRES TO EGG-YOLK DILUENT AND \\
THE FREQUENGY OF SERVIGE \\
\hline
\end{tabular}

\begin{tabular}{l|rcl}
\hline & \multicolumn{3}{|c}{ No. of services } \\
& 0 & 1 to 3 & $\geqslant 4$ \\
\hline $\begin{array}{l}\text { No. of animals tested } \\
\text { No. showing titres }\end{array}$ & 20 & 40 & 49 \\
$\%$ showing titres & 1 & 15 & 37 \\
\hline
\end{tabular}

found in the uterine samples from the majority of animals served four or more times (repeat-breeders).

The antibody titres found in the uterine samples ranged from 64 to 256, with the higher titres occurring in the animals with the greater number of services.

Samples from eighty of these animals were examined for antibodies to spermatozoa and seminal plasma. Of these, two animals which had been served five and seven times, gave titres of 32 and 64, respectively.

To determine the site of origin of the antibody found in the uterus, samples taken simultaneously from the vagina, uterus and serum of sixty-eight cows were examined. Only tests for antibody to egg-yolk diluent were carried out.

The frequency with which positive titres were obtained from these samples is given in Table 2. These results show that the vagina was the site from which antibodies were isolated most frequently, while the lowest immunological response was found in the serum samples. 
Although antibodies were shown to be present in the vagina and uterus of many of these cows, the source of these antibodies was not known. A correlation between the titres found in the serum and vagina of a selected group of animals is given in Table 3. This shows that, of twenty-three animals which had positive titres in the vagina, nineteen had positive serum titres. Of these nineteen animals, ten had vaginal titres greater than those found in the serum.

Four animals had vaginal titres in the absence of any humoral response so that of twenty-three animals which had vaginal titres, fourteen had titres which could not be accounted for entirely by the passage of humoral antibody into the tissues of the genital tract. This can be explained by the production of local antibody by the vagina following exposure to diluent antigens.

TABLE 2

RELATIONSHIP BETWEEN ANTIBODIES TO EGG-YOLK DILUENT AND FREQUENGY OF SERVIGE BY AI

\begin{tabular}{l|ccc}
\hline & \multicolumn{4}{|c}{ No. of services by AI before testing } \\
& $0 *$ & 1 to 3 & $\geqslant 4$ \\
\hline Serum positive & $0 / 10$ & $12 / 25$ & $18 / 31$ \\
$\%$ positive & 0 & 48 & 58 \\
Vaginal biopsy positive & $0 / 7$ & $10 / 14$ & $13 / 15$ \\
$\%$ positive & 0 & 71.5 & 86.7 \\
Uterine biopsy positive & $1 / 6$ & $7 / 12$ & $8 / 12$ \\
$\%$ positive & 16.7 & 58.4 & 66.7 \\
\hline
\end{tabular}

* This includes animals served naturally, which had not been brought into contact with semen diluent at service.

TABLE 3

GORRELATION BETWEEN VAGINAL AND SERUM TITRES OF ANTIBODY TO EGG-YOLK DILUENT ANTIGENS

\begin{tabular}{l|cccc}
\hline & Vaginat & $\begin{array}{c}\text { Vaginat } \\
\text { Serum }\end{array}$ & $\begin{array}{c}\text { Vaginat } \\
\text { Serum- }\end{array}$ & $\begin{array}{c}\text { Vagina- } \\
\text { Serum }\end{array}$ \\
\hline $\begin{array}{c}\text { No. of animals with antibody } \\
\text { titres to egg-yolk diluent }\end{array}$ & 23 & 19 & 4 & 2 \\
\hline
\end{tabular}

A similar comparison was made between uterine and serum titres. Although the antibody titres found in uterine homogenates were lower than those in the vagina, they were also found both in excess and in the absence of serum titres.

Tests were carried out in vitro to determine the effect of these antibodies on semen homologous to that used in the service. Fresh semen and semen which had been diluted and stored in egg-yolk diluent was washed and tested for sperm agglutination and immobilization. Samples which had titres to diluent antigens in the passive haemagglutination test caused mixed agglutination of the spermatozoa which had been stored in egg-yolk diluent but did not have any effect on the semen which was stored and diluted in saline, except for causing non-specific head-to-head agglutination. Immobilization of spermatozoa was not demonstrated using spermatozoa stored in egg-yolk diluent or saline. 
The fertility of forty animals from which samples had been obtained following the first, second or third service was examined in order to evaluate the effect of antibodies to the egg-yolk diluent. The fertility of fifteen animals which had uterine titres following a given service was significantly lower $(P \geqslant 0.05)$ than the fertility of twenty-five animals in which there were no uterine titres (Table 4).

TABLE 4

THE ASSOCIATION BETWEEN UTERINE ANTIBODIES TO EGGYOLK DILUENT AND FERTILITY

\begin{tabular}{l|cc}
\hline & $\begin{array}{c}\text { Uterine titres to diluent antigen } \\
+\end{array}$ & - \\
\hline $\begin{array}{l}\text { No. of animals } \\
\begin{array}{l}\text { No. repeating to the service following } \\
\text { which the sample was obtained }\end{array} \\
\text { \% repeating to the service }\end{array}$ & 15 & 25 \\
\hline
\end{tabular}

* Differences significant at $P \geqslant 0.05$.

Uterine titres of antibody to semen were found so infrequently that they could not be associated with the reduced breeding efficiency.

\section{DISCUSSION}

Although Bratanov \& Dikov (1959) and Sokolovskaja \& Reshetnikova (1968) have found antibodies to homologous spermatozoa in the serum of cattle following service, it would appear that semen provides a weak immunological challenge to cattle under these conditions. Chemical adjuvants must be used in conjunction with homologous semen to induce antibodies in cattle under experimental conditions (Kiddy et al., 1959; Menge, 1967). Bratanov, Dikov, Radev $\&$ Danov $(1965,1966)$ have found increased titres of iso-antibodies to spermatozoa following service of animals suffering from such diseases as latent chronic endometritis or oestrual metrorrhagia, and they suggest that there may be an accelerated absorption of spermatozoa which induces serum titres of antibody with greater facility than in normal animals.

Bratanov et al. $(1965,1966)$ did not attempt to assess the antifertility effect of the humoral iso-antibodies to semen nor did they establish the significance of such antibodies within the genital tract. Menge (1967) found that, following iso-immunization of heifers with semen, antibody titres could be found concurrently in the serum and the uterus, and that there was a direct correlation between the level of titres in the uterus and the breeding efficiency of the host. The extremely low incidence of uterine titres to homologous semen $(2.5 \%)$, found in the present work, would suggest that under natural conditions, high titres of antibodies to semen are not frequently produced even in animals served repeatedly.

In contrast to this, antibodies to egg-yolk semen diluent antigens were frequently detected in the vagina, uterus and serum of cattle after repeated service by AI. Our results would suggest that these antibodies may be produced locally in the genital tract of cattle and/or in the humoral system, following 
service. The important factor is that, irrespective of the site of production, the antibodies may be present within the genital tract and therefore could affect the fertility of the female.

The different agglutination patterns obtained in vitro on testing homologous spermatozoa which had been stored in egg-yolk diluent or saline, with samples which had titres to diluent protein, would suggest that storage of spermatozoa in egg-yolk diluent alters their antigenicity. Under natural conditions, seminalplasma antigens become attached to the mammalian sperm surface as the spermatozoa pass through the male genital tract (Weil \& Rodenburg, 1962). The negatively charged surface of the bovine sperm surface (Veres \& Oscenyi, 1968) would provide an optimal environment for the ionic binding of protein molecules, such as egg-yolk diluent protein. Such a reaction could cause occlusion of the normal antigenic sites of the spermatozoa and confer on them an antigenicity similar to diluent protein, thus making them sensitive to agglutination by antibody specific for egg-yolk diluent antigen. Bratanov, Dikov \& Tornjov (1968) have found similar types of agglutination patterns with the immune serum from rabbits immunized with bovine semen diluted in egg-yolk diluent. Swanson \& Hunter (1969) have demonstrated clumping when rabbit spermatozoa, which had been diluted in egg-yolk diluent, were mixed with specific antisera for the egg-yolk diluent antigen. No agglutination or immobilization could be demonstrated with the antisera.

A reduction in fertility of animals to service with semen diluted in egg-yolk diluent was found in the present work, when uterine titres to diluent antigens were present, as compared with animals showing no titres. From these results, it would appear that the presence of antibodies to egg-yolk diluent in the bovine uterus, is detrimental to the fertility of AI service. Swanson \& Hunter (1969) have shown that rabbit antisera to egg-yolk semen diluent alone does not reduce the fertility of semen stored in homologous diluent, when used to treat the semen before insemination. They propose that the presence of these antibodies within the tissues of the uterus may interfere with fertility.

Preliminary results have shown that the fertility of rabbits to insemination with semen diluted in egg-yolk diluent was significantly reduced in animals which had high titres of antibody to diluent antigen. Ten of eleven rabbits which had uterine mucus titres of less than 64 were fertile following insemination, whereas none of seven animals with mucus titres equal to or greater than 64 was fertile. Although a direct correlation was found between antibodies to egg-yolk diluent and infertility, no relationship could be found between reduced fertility and uterine titres to seminal antigens (Griffin, McGilligan, Hartigan \& Nunn, in preparation). From our results, it would appear, therefore, that the presence of antibodies to semen diluent antigens in the uterus of cows or rabbits can have an adverse effect on the breeding performance.

\section{ACKNOWLEDGMENTS}

We wish to thank the Agricultural Institute, Chemical Services Ltd, and the Ballyclough and Galtee Gattle Breeding Stations for their financial support and the provision of technical facilities.

We are also grateful to Professor J. T. Baxter for his interest in this work. 


\section{REFERENCES}

Ashitaka, Y., Isojma, S. \& Ukita, H. (1964) Mechanism of experimental sterility induced in guinea pigs by injection of homologous testis and sperm. II. Relationship between sterility and a sperm-immobilizing antibody. Fert. Steril. 15, 213.

Behrman, S. J. \& Nakayama, M. (1965) Antitestis antibody: its inhibition of pregnancy. Fert. Steril. $16,37$.

BeLL, E. B. (1969a) Immunological control of fertility in the mouse: a comparison of systemic and intravaginal immunization. F. Reprod. Fert. 18, 183.

BeLL, E. B. (1969b) Iso-antibody formation against rabbit spermatozoa and its effect on fertility. $\mathcal{J}$. Reprod. Fert. 20, 519.

BoYDEn, S. V. (1951) The adsorption of proteins on erythrocytes treated with tannic acid and subsequent haemagglutination with antiprotein sera. . exp. Med. 93, 107.

Bratanov, K. \& Dikov, V. (1959) Investigations on spermoisoagglutination in connection with the fertilization of cows. Nauchni Trud. nauchno-izled. Inst. Razvad. Bol. izskustv. Osemen. selskostop. Zivotn. (Sofija), 1, 11. Anim. Breed. Abstr. 30, No. 965.

Bratanov, K., Dikov, V. \& Popova, J. (1962) On some agglutination phenomena of bovine spermatozoa when diluted in egg-yolk and preserved with antibiotics. Akad. na Selsk. Nauk. Sofia Nauchno-izsled. Inst. po Biol. i Patol. na Razmnozhavaneto na Selsk. Zhivotni Izv. 3, 11.

Bratanov, K., Dikov, V., Radev, G. \& Danov, D. (1965) Investigations on the immunology of reproduction. VII. On the role of spermoantibodies in the insemination of cows with incomplete involution of the uterus and cows having latent endometritis. Vet. Sci. 2, 323.

Bratanov, K., Dikov, V., Radev, G. \& Danov, D. (1966) Investigations on the immunology of reproduction. VIII. On the role of spermoantibodies in repeated insemination of cows having oestral metrorrhagia. Nauchni Trud. vissh selskostop. Inst. Georgi Dimitrov, 16, 333.

Bratanov, K., Dikov, V. \& Tornjov, A. (1968) Sur la spécificité des antigènes de spermatozoïdes dans le sperme du taureau. VIe Congr. Int. Reprod. Anim. Insem. Artif., Paris, 1, 529.

EDWARDs, R. G. (1960) Antigenicity of rabbit semen, bull semen and egg yolk after intravaginal or intramuscular injections into female rabbits. $\mathcal{F}$. Reprod. Fert. 1, 385.

Edwards, R. G. (1964) Immunological control of fertility in female mice. Nature, Lond. 203, 50.

Franklin, R. R. \& Dukes, C. D. (1964) Antispermatozoal antibody and unexplained infertility. Am. F. Obstet. Gynec. 89, 6.

Isojma, S., Graham, R. J. \& Graham, J. B. (1959) Sterility in female guinea pigs induced by injection with testis. Science, N.Y. 129, 44.

KATsh, S. (1959) Infertility in female guinea pigs induced by injection of homologous sperm. Am. $\mathcal{J}$. Obstet. Gynec. 78, 276.

Kiddy, C. A., Stone, W. H., Tyler, W. T. \& Casida, L. E. (1959) Immunological studies on fertility and sterility. III. Effect of isoimmunization with blood and semen on fertility in cattle. $\mathcal{J}$. Dairy Sci. 42, 110.

Kilbrick, S., Balding, D. L. \& Merrill, B. (1952) Methods for detection of antibodies against mammalian spermatozoa. II. Gelatin agglutination technique. Fert. Steril. 3, 430.

LANdsteiner, K. (1899) Zur Kenntnis der spezifisch auf Blutkorperchen wirkenden Sera. Zentbl. Bakt. Parasitkde, 25, 546.

McLaren, A. (1964) Immunological control of fertility in female mice. Nature, Lond. 201, 582.

Menge, A. C. (1967) Induced infertility in cattle by iso-immunization with semen and testis. F. Reprod. Fert. 13, 445.

Menge, A. C. (1968) Fertilization, embryo and fetal survival rates in rabbits isoimmunized with semen, testis and conceptus. Proc. Soc. exp. Biol. Med. 127, 1271.

MURPHy, J. A. (1967) An investigation into the microbiology of the genital tract of normal and repeat-breeding dairy cows in Ireland. Ph.D. thesis, Dublin University.

Soxolovskaja, I. I. \& Reshetnikova, N. M. (1968) Immunological factors in fertilization and early embryonic development. Zhivotnovodstvo, Mosk. 6, 65.

Swanson, L. V. \& Hunter, A. G. (1969) Egg-yolk antigens and their effect on fertility in rabbits. Biol. Reprod. 1, 324.

Tyler, A., Tyler, E. T. \& Denny, P. G. (1967) Concepts and experiments in immunoreproduction. Fert. Steril. 18, 153.

VEREs, I. \& OSCENYI, A. (1968) Recent results obtained from ultrastructural examination of bull sperm cells. VIe Congr. Int. Reprod. Anim. Insem. Artif., Paris, 1, 213.

Wales, R. G., Martin, L. \& O'Shea, T. (1967) Effect of dilution rate and number of spermatozoa inseminated on the fertility of rabbits ovulated with chorionic gonadotrophin. F. Reprod. Fert. 10, 69.

WeIL, A. J. \& Rodenburg, J. M. (1962) The seminal vesicle as a source of the spermatozoa coating antigen of seminal plasma. Proc. Soc. exp. Biol. Med. 109, 567.

WeIR, D. M. (1967) Handbook of experimental immunology. Blackwell Scientific Publications, Oxford. 